\title{
Silver and Gold on the Hairs of Holy Maria-Magdalena, Studied by Scanning Electron Microscopy and Elemental Analysis
}

\author{
Gérard Lucotte \\ Institut d'Anthropolgie Moléculaire, Paris, France \\ Email:lucotte@hotmail.com
}

How to cite this paper: Lucotte, G. (2019). Silver and Gold on the Hairs of Holy Maria-Magdalena, Studied by Scanning Electron Microscopy and Elemental Analysis. Archaeological Discovery, 7, 257-282. https://doi.org/10.4236/ad.2019.74012

Received: August 31, 2019

Accepted: October 8, 2019

Published: October 11, 2019

Copyright $\odot 2019$ by author(s) and Scientific Research Publishing Inc. This work is licensed under the Creative Commons Attribution International License (CC BY 4.0).

http://creativecommons.org/licenses/by/4.0/

\begin{abstract}
We have studied by optical microscopy and by SEM-EDX some metallic particles of silver and gold adhering to the Maria-Magdalena hairs. The presence of silver particles is explained by the contact between hairs and the inner side made of silver of the initial reliquary where Maria-Magdalena remains were kept. Presence of gold particles is also explained by the contact between hairs and the gold of the bust-reliquary where hairs of Maria-Magdalena hairs were kept between 1283 and 1793 .
\end{abstract}

\section{Keywords}

Maria-Magdalena's Hair, SEM-EDX Analyses, Silver and Gold Particles, Successive Reliquaries Where Maria-Magdalena’s Remains Were Kept, Calcium Phosphate Deposits, Other Metallic Particles

\section{Introduction}

Holy Maria-Magdalena (3?-63?) is the most abundantly cited woman in the four Gospels. There were some places (notably Palestine) where Maria-Magdalena could be buried, but according to the French "tradition des Saints de Provence" (Trouillet, 2016) she (and her companions) landed to the present French Mediterranean shores (in a region corresponding to the current part of Les-Saintes-Marie-de-la-mer) and attained further the towns of Marseilles and Aix-en-Provence.

Some relics (cranium, bones and hairs) of the presumed Maria-Magdalena were kept in the Saint-Maximin basilica, where a large lock of Maria-Magdalena's hair is kept in a dedicated reliquary. We have obtained some hairs from this lock, for scientific purposes (microscopic examinations and 
chemical analyses). We have published these last years the mitochondrial DNA haplogroup found by extracting genomic DNA from the bulb of hair number 10 (Lucotte, 2016), the explanation of the brown-red observed colour of the hairs by scanning electron microscopic characterisation of its melanosomes (Lucotte \& Thomasset, 2017a), the description of some fennel rests on or at the vicinity of some of these hairs (Lucotte et al., 2018) and marine micro-remains loaded on the hairs (Lucotte et al., 2019).

In the present study, we describe and analyse silver and gold metallic deposits on some of these hairs, by SEM (Scanning Electron Microscopy) and EDX (Energy Dispersive X-ray spectroscopy) analysis.

\section{Material and Methods}

The material is ten of the lock of Maria-Magdalena's hairs that were kept in the dedicated reliquary located in the Saint-Maximin basilica. These hairs, numbered 1 to 10 , were loaded on a sterile sticky paper for optical microscopy, SEM and EDX analysis.

All the hairs were examined in confocal stereoscopic micrography. The SEM apparatus used for metallic deposits observations is the FEI model Quanta FEG (an environmental electron microscope apparatus). Elemental analysis of deposits was achieved by using EDX, this SEM microscope being equipped with the probe model X-flash 6/30. Both LFD (Large Field Detector) and CBS (Circular Back Scattering) were used, the last one to better detect heavy elements. Each elemental analysis is given in the form of a spectrum, with kiloelectrons/Volts $(\mathrm{ke} / \mathrm{V})$ on the abscissa and elemental peaks heights (cps/eV) in ordinates.

\section{Results and Discussion}

There are numerous particles of silver and of gold on the surface of hair numbers 1, 2, 3, 4 and 9. As an example Figure 1 shows an optical view of some portion of hair number 2 where silver is present under the form of a longitudinal line running along all the hair border, and gold under the form of three local deposits.

\subsection{Silver}

Figure 2 shows a MEB photograph of some part of the longitudinal line; EDX analysis establishes that it is mainly compounded of silver (of the chloride form, which is the most stable). Two other parts of the line are shown on Figure 3, which are of the same elemental composition. In a fourth part of the line (Figure 4), the height of the chlorine peak is as elevated as that of the silver main peak.

Figure 5 shows a granulous particle (of about $3 \mu \mathrm{m}$ of length), located on hair number 1. Elemental analysis of this particle establishes that it is compounded of a mixture of silver chloride and sulphide. Figure 6 shows another particle, also located on hair number 1 that is of silver sulphide with gold. Figure 7 shows another particle located on hair number 2 that is a plaque (of more than $5 \mu \mathrm{m}$ of 


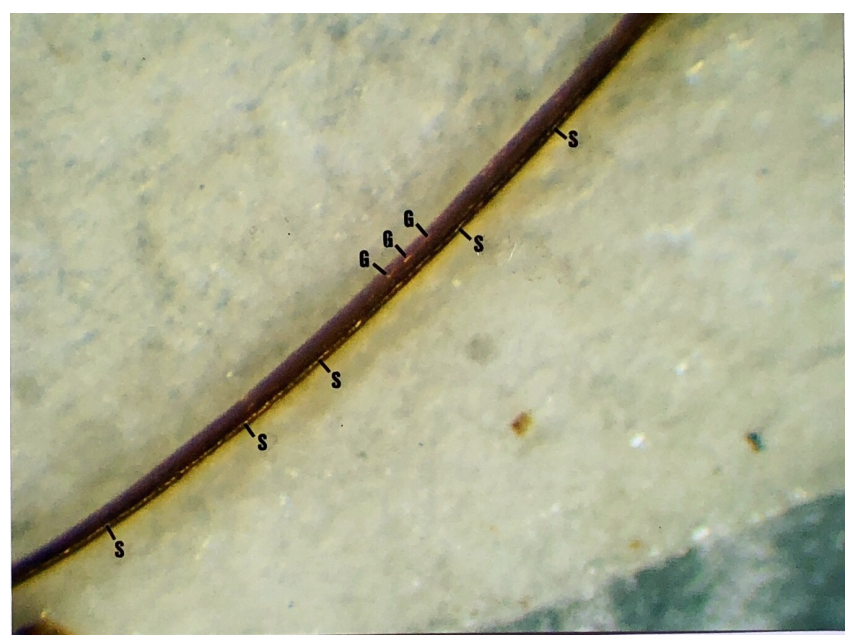

Figure 1. Optical view $(20 \times)$ of a portion of hair number 2. S: silver; G: gold.

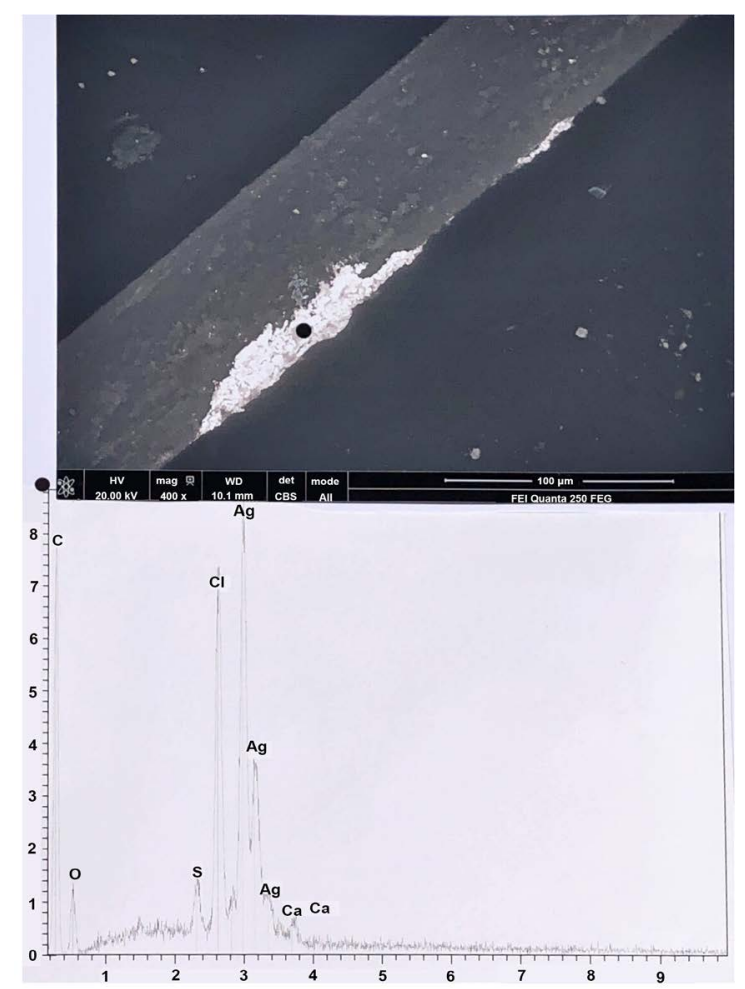

Figure 2. One deposit of silver chloride on hair number 2. Above: SEM photograph (in CBS, 400x) of the deposit (the black point indicates the location where EDX analysis is realized). Below: spectrum at the black point. C: carbon; O: oxygen; S: sulphur; Cl: chlorine; Ag (three peaks): silver; $\mathrm{Ca}$ (two peaks): calcium.

length) of silver sulphide with some traces of copper. Figure 8 a voluminous (of more than $150 \mu \mathrm{m}$ of length on about $50 \mu \mathrm{m}$ of width) rectangular plaque, located at the vicinity of some part of hair number 4 , that is compounded of many parts of pure silver. 


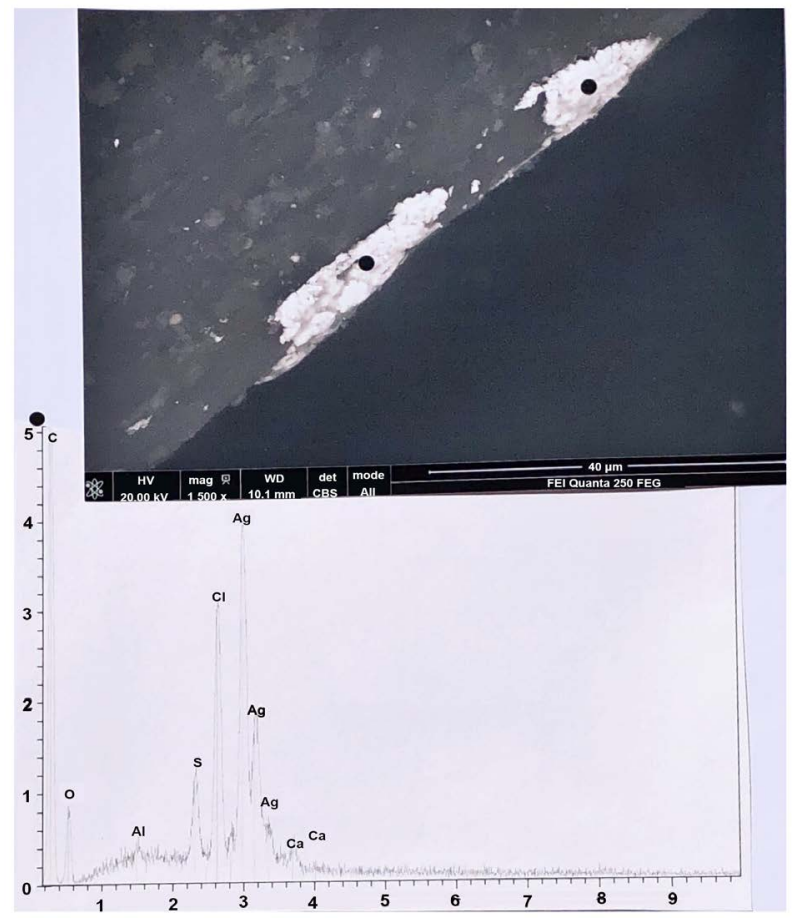

Figure 3. Two other deposits of silver chloride on hair number 2. Above: SEM photograph (in CBS, 1500×) of the two deposits. Below. spectrum at the black points.

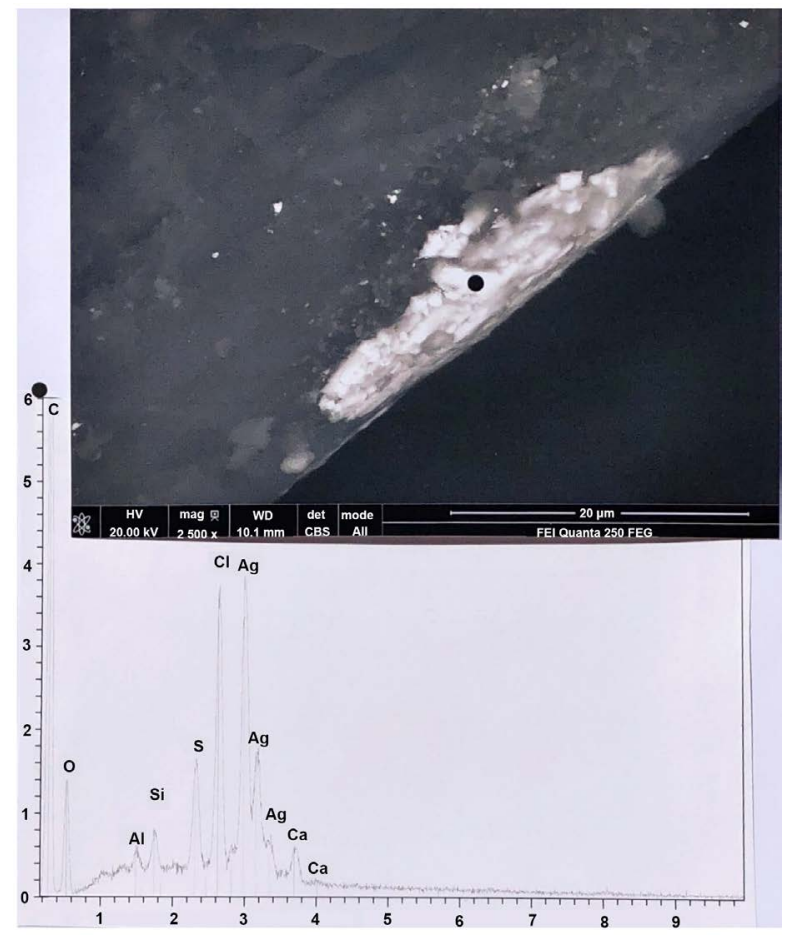

Figure 4. A fourth deposit of silver chloride on hair number 2. Above: SEM photograph (in CBS, 2500x) of the deposit. Below: spectrum at the black point. C: carbon; O: oxygen; $\mathrm{Al}$ : aluminium; Si: silicium; S: sulphur; $\mathrm{Cl}$ : chlorine, $\mathrm{Ag}$ (three peaks): silver; $\mathrm{Ca}$ (two peaks): calcium. 


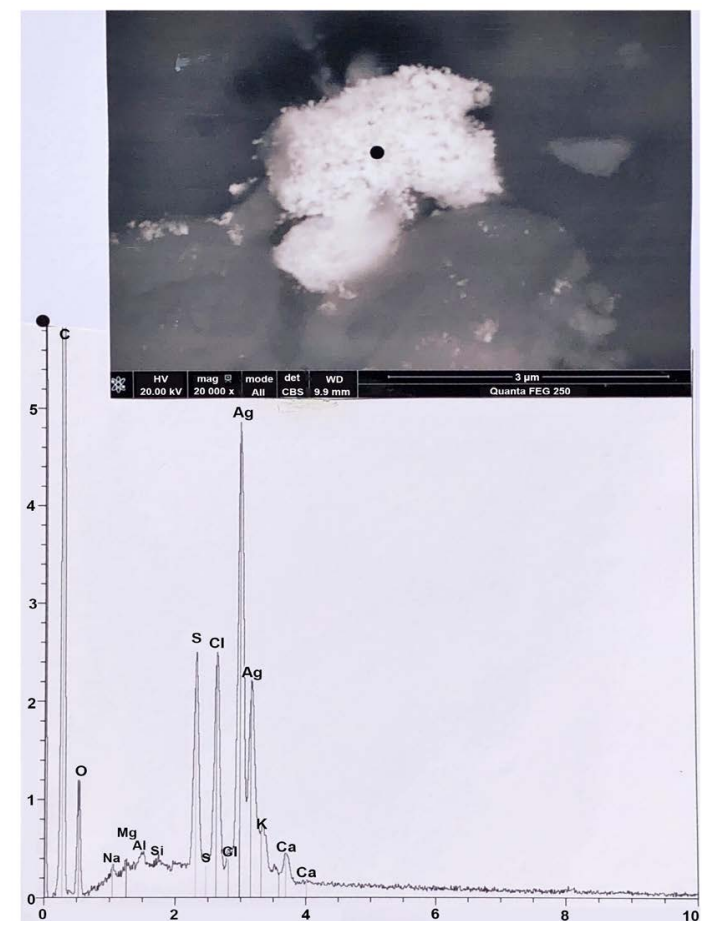

Figure 5. A particle, located on hair number 1 that is a mixture of silver chloride and sulphide. Above: SEM photograph (in CBS, 20000x) of the particle. Below. spectrum at the black point. C: carbon; O: oxygen; Na: sodium; Mg: magnesium; Al: aluminium; Si: silicium; $\mathrm{S}$ (two peaks): sulphur; $\mathrm{Cl}$ (two peaks): chlorine; Ag (two peaks): silver; K: potassium; $\mathrm{Ca}$ (two peaks): calcium.

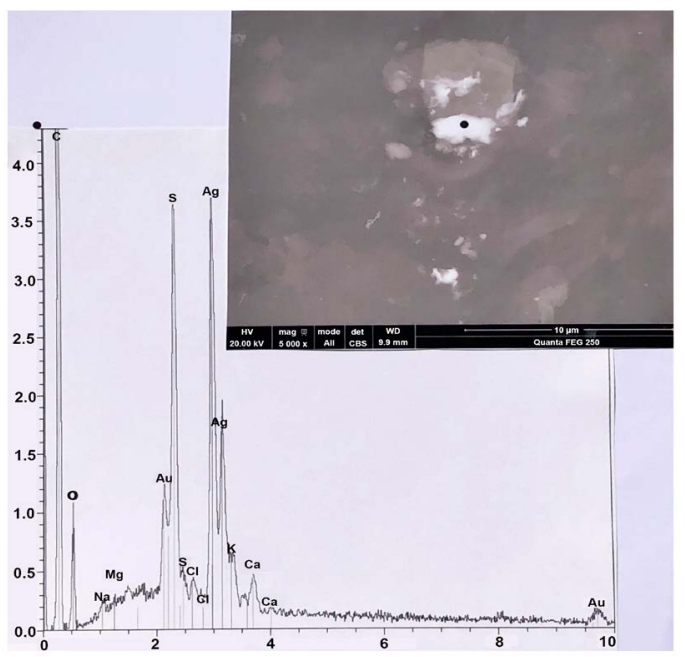

Figure 6. Another particle located on hair number 1 that is of silver sulphide with gold. Above: SEM photograph (in CBS, 5000x) of the particle. Below: spectrum at the black point. C: carbon; O: oxygen; Na: sodium; Mg: magnesium; $\mathrm{Au}$ (two peaks): gold; $\mathrm{S}$ (two peaks): sulphur; $\mathrm{Cl}$ (two peaks): chlorine; Ag (two peaks): silver; K: potassium; Ca (two peaks): calcium. 


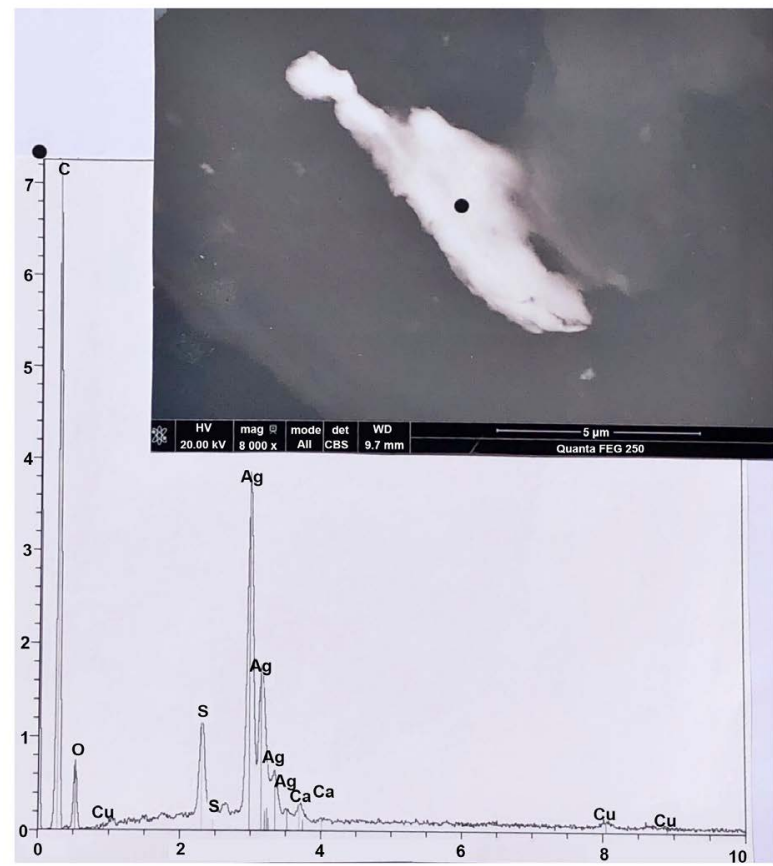

Figure 7. A plaque, located on hair number 1 that is of silver sulphide with copper. Above: SEM photograph (in CBS, $8000 \times$ ) of the plaque. Below: spectrum at the black point. C: carbon; O: oxygen; $\mathrm{Cu}$ (three little peaks): copper; $\mathrm{S}$ (two peaks): sulphur; Ag (four peaks): silver; Ca (two peaks): calcium.

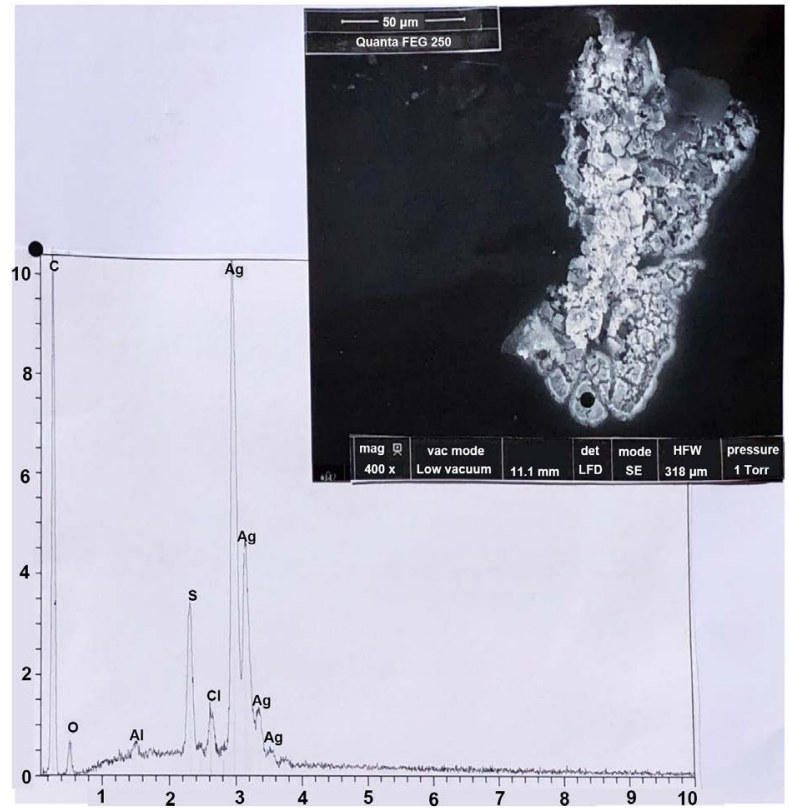

Figure 8. A voluminous plaque of pure silver, that is located at the vicinity of hair number 4. Above: SEM photograph (in LFD, 400 $\times$ ) of the plaque. Below. spectrum at the black point. C: carbon; O: oxygen; Al: aluminium; S: sulphur; $\mathrm{Cl}$ : chlorine; Ag (four peaks): silver. 


\subsection{Gold}

Figure 9 is a SEM photograph of one of the three particles of gold, depicted on Figure 1, located on hair number 2; it is a multi-lobed particle of about $1.5 \mu \mathrm{m}$ of maximal length. Its elemental analysis establishes that it is mainly compounded of gold (in fact an alloy, with $8.5 \%$ of silver and $2.2 \%$ of copper). The sulphur content in the sample is, as for all of the gold particles studied here, more elevated than that found in ancient hairs (Lucotte \& Thomasset, 2017b); it is deduced that this elemental level in sulphur is mainly due to pollution. The composition of the particle located on hair number 3 (Figure 10) is also that of an alloy of gold, silver and copper. But in the plaque, also located on hair number 3 (Figure 11), the alloy is mainly of gold with traces of copper; it is also the case for a second smaller plaque (Figure 12), located on hair number 1, and for a third plaque (Figure 13), but with silver, located on hair number 1.

Figure 14 shows an example of grains of gold dust, located on hair number 9. Figure 15 shows examples of two little particles of gold (of a gold powder), located on hair number 3 . Figure 16 shows an example of a scale of pure gold, of a relatively great size (of more than $2 \mu \mathrm{m}$ of maximal length), which is located on hair number 9.

\subsection{Copper}

There is only one piece of pure copper (Supplementary Figure 1). It is a little plaque of this metal, located on the surface of hair number 3. Most of the copper-compounded pieces found are particle of brass: Supplementary Figure 2 shows one of them, also located on hair number 3; there are other plaques of brass, located near hair number 6 and between hairs 9 and 10. Probably they are fragments pulled up to the metal of the reliquary. Supplementary Figure 3 shows a group of little copper-made particles (calibrated at about $5 \mu \mathrm{m}$ of length, and of a manufactured form), located on some part of hair number 6. Elemental analyses establish that they are particles of copper sulphate; they are powder members of a classical phytosanitary product. Such groups of copper sulphate particles occur also on two other parts of hair number 6 , and on hair number 10.

\subsection{Other Metallic Particles}

\subsubsection{Lead}

There is only one piece compounded of lead (Supplementary Figure 4), that is located on hair number 9. It is a round (less than $5 \mu \mathrm{m}$ ) particle of composite appearance; elemental analysis establishes that it corresponds to lead phosphate, another phytosanitary product used in the past.

\subsubsection{Iron}

Supplementary Figure 5 shows a little white-to-electrons particle, located on the hair number 3 border. Elemental analysis establishes that it is a particle of iron oxide, a metallic industrial pollutant commonly found in all samples studied. Such pollutant commonly found in all samples studied. Such pollutant 


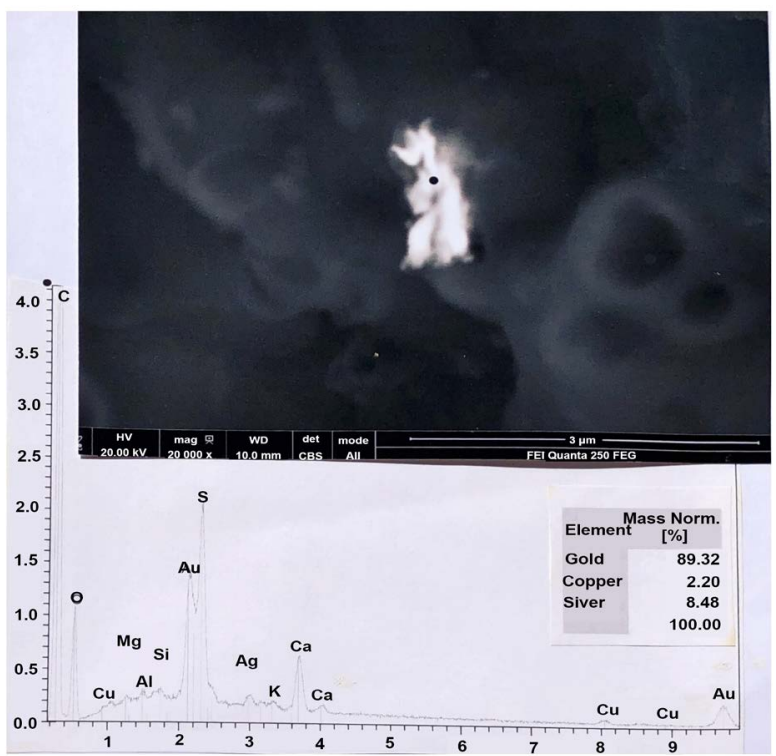

Figure 9. A particle of gold, located on hair number 2. Above: SEM photograph (in CBS, 20000x) of the particle. Below: spectrum at the black point. C: carbon, O: oxygen; $\mathrm{Cu}$ (three peaks): copper; Mg: magnesium; Al: aluminium; Si: silicium; Au (two peaks): gold; S: sulphur; Ag: silver; K: potassium; Ca (two peaks): calcium. Insert: relative percentages of gold, copper and silver in the alloy.

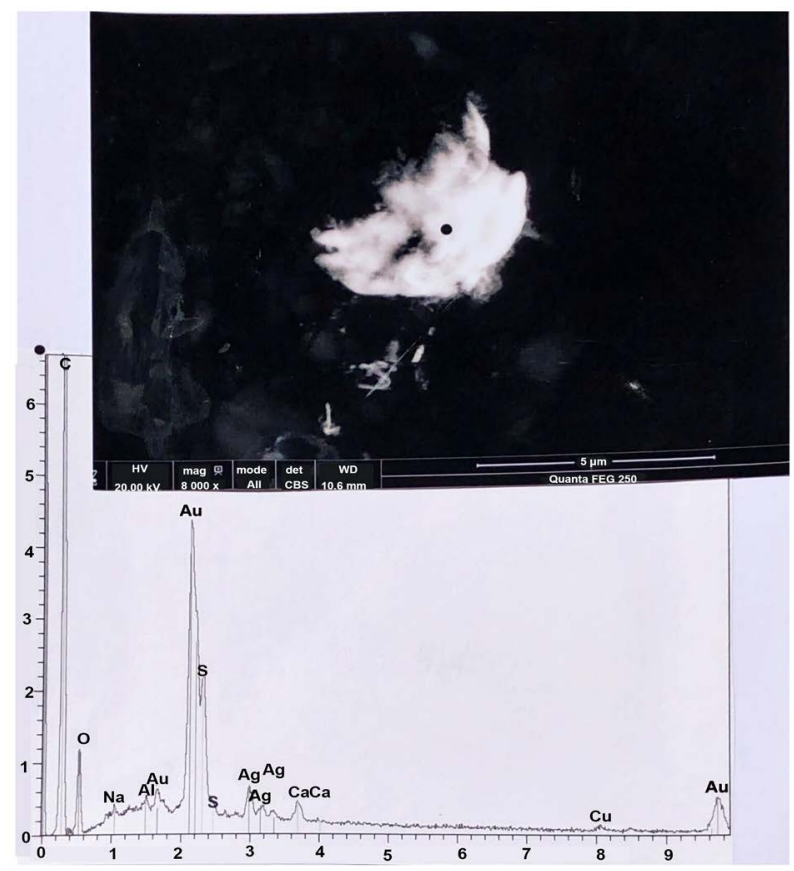

Figure 10. A particle of gold, located on hair number 3 . Above: SEM photograph (in CBS, $8000 \times$ ) of the particle. Below: spectrum at the black point. C: carbon; O: oxygen; Na: sodium; Al: aluminium; Au (three peaks): gold; S (two peaks): sulphur; Ag (three peaks): silver; Ca (two peaks): calcium; $\mathrm{Cu}$ : copper. 


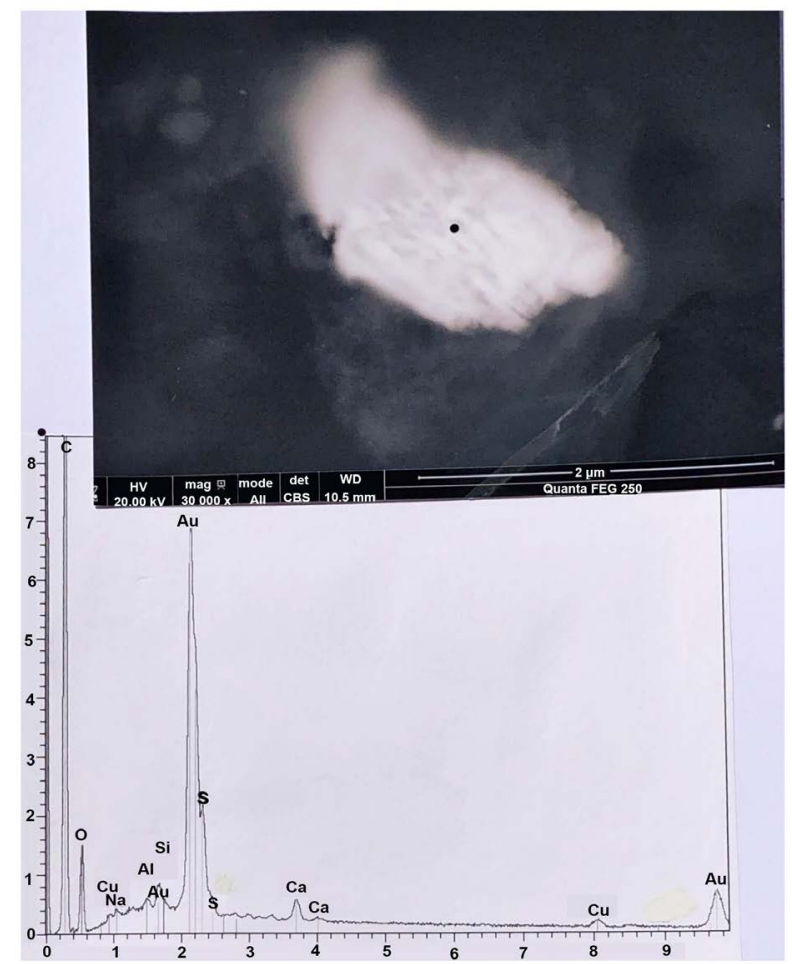

Figure 11. A plaque of gold, located on hair number 3 . Above: SEM photograph (in CBS, $30000 \times$ ) of the plaque. Below: spectrum at the black point. C: carbon; O: oxygen; $\mathrm{Cu}$ (two peaks): copper; Na: sodium; $\mathrm{Al}$ : aluminium; $\mathrm{Au}$ (three peaks): gold; Si: silicium; $\mathrm{S}$ (two peaks): sulphur; $\mathrm{Ca}$ (two peaks): calcium.

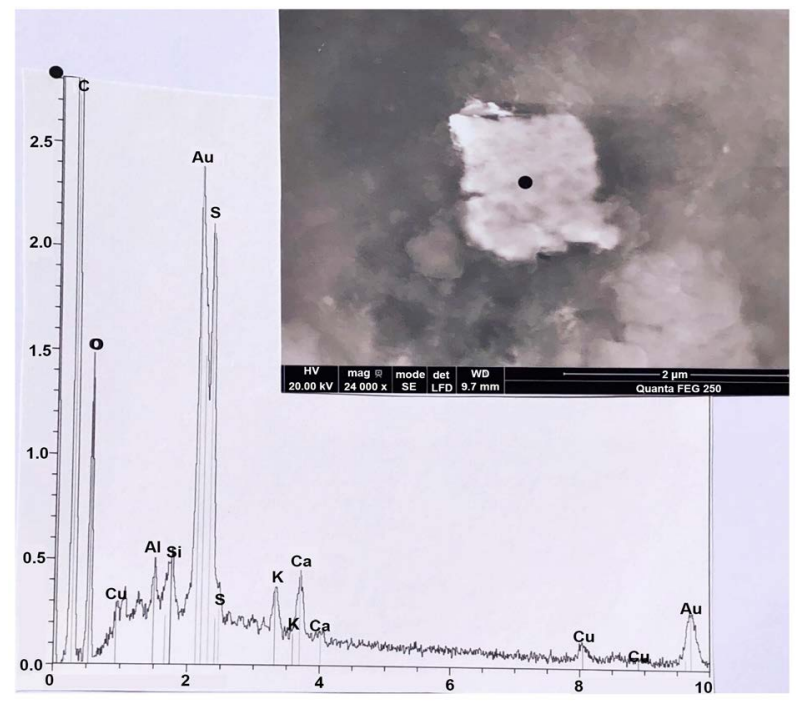

Figure 12. A second plaque of gold, located on hair number 1. Above: SEM photograph (in CBS, $24000 \times$ ) of the plaque. Below. spectrum at the black point. C: carbon; O: oxygen; $\mathrm{Cu}$ (three peaks): copper; Al: aluminium; Si: silicium; Au (two peaks): gold; S (two peaks): sulphur; $\mathrm{K}$ (two peaks): potassium; Ca (two peaks): calcium. 


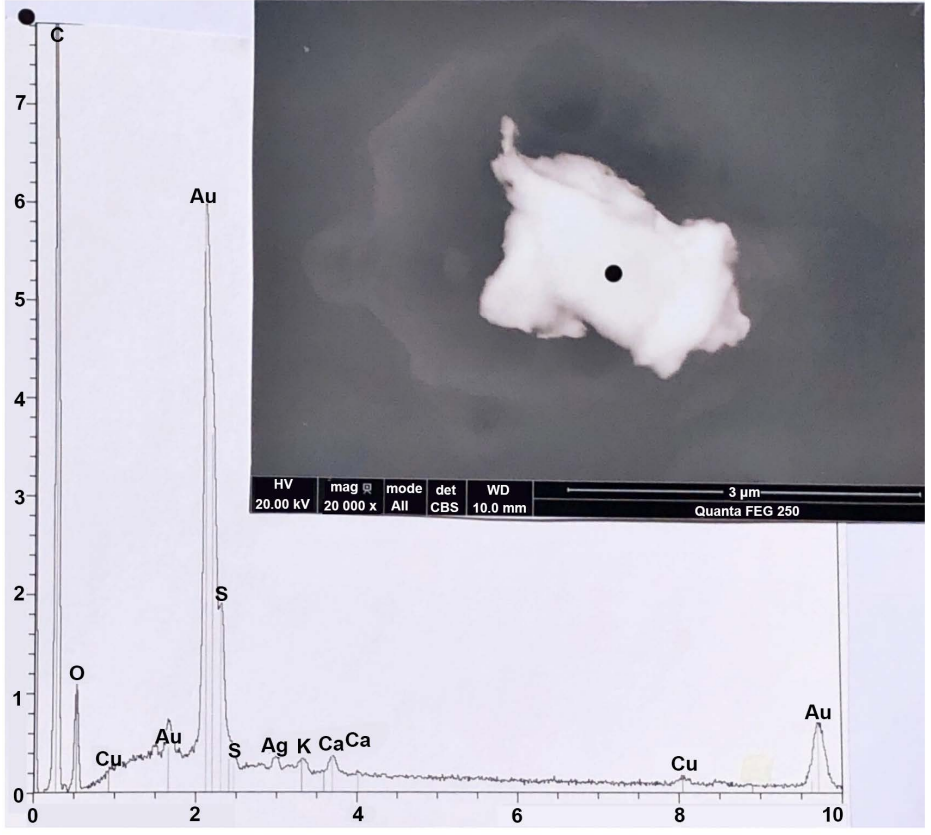

Figure 13. A third plaque of gold, located on hair number 1. Above: SEM photograph (in CBS, $20000 \times$ ) of the plaque. Below: spectrum at the black point. C: carbon; O: oxygen; $\mathrm{Cu}$ (two little peaks): copper; $\mathrm{Au}$ (three peaks): gold; Ag: silver; S (two peaks): sulphur; K: potassium; Ca (two peaks): calcium.

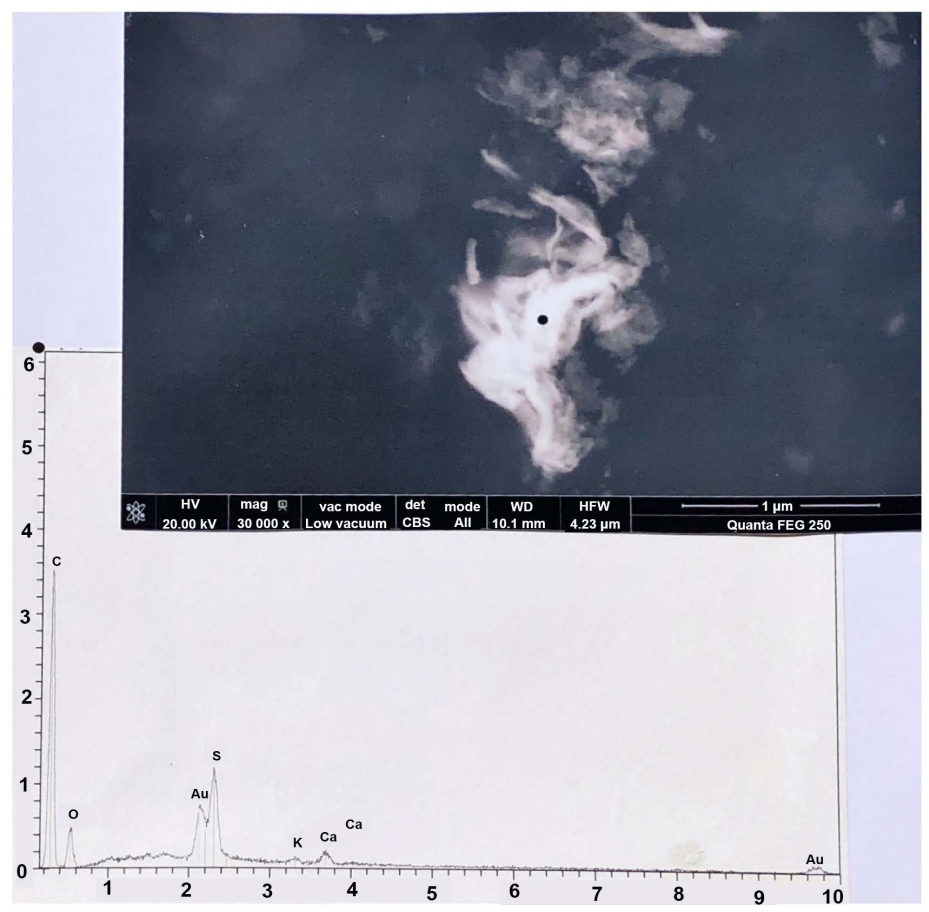

Figure 14. Grains of gold dust, on hair number 9. Above: SEM photography (in CBS, 30000x) of the dust. Below. spectrum at the black point. C: carbon; O: oxygen; Au (two peaks): gold; S: sulphur; K: potassium; Ca (two peaks): calcium. 


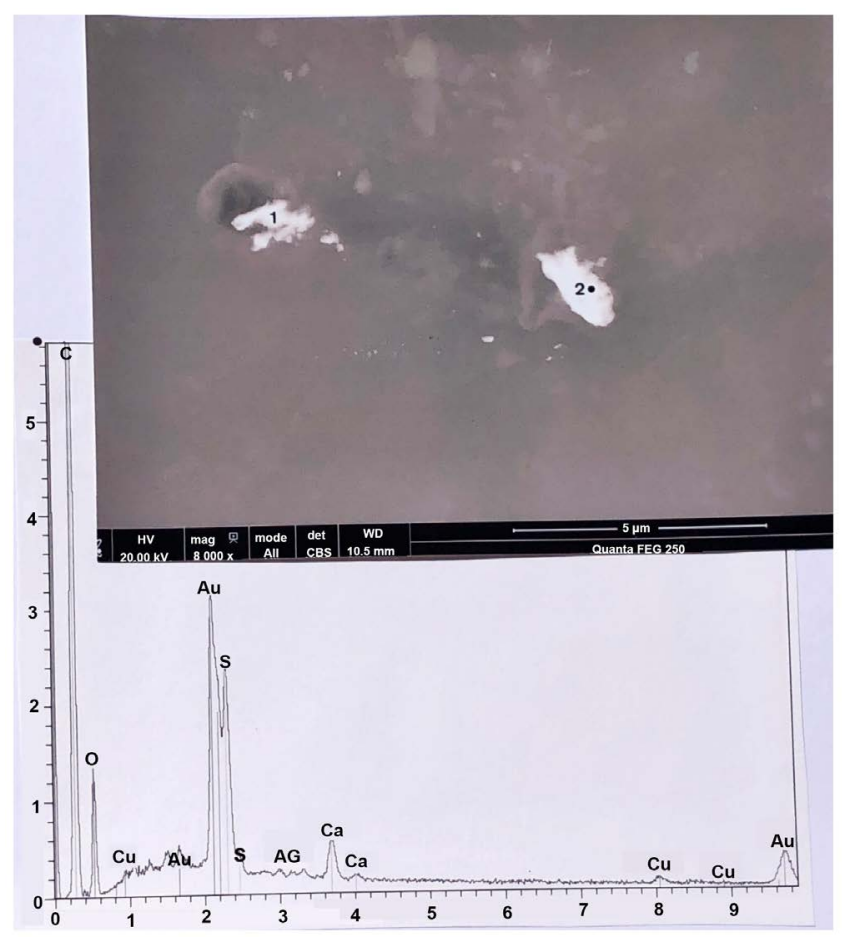

Figure 15. Two little particles of gold, on hair number 3. Above: SEM photography (in CBS, 8000x) of the particles 1 and 2. Below: spectrum at the black point of 2. C: carbon; O: oxygen; $\mathrm{Cu}$ (three peaks): copper; $\mathrm{Au}$ (three peaks): gold; S (two peaks): sulphur; Ag: silver; Ca (two peaks): calcium.

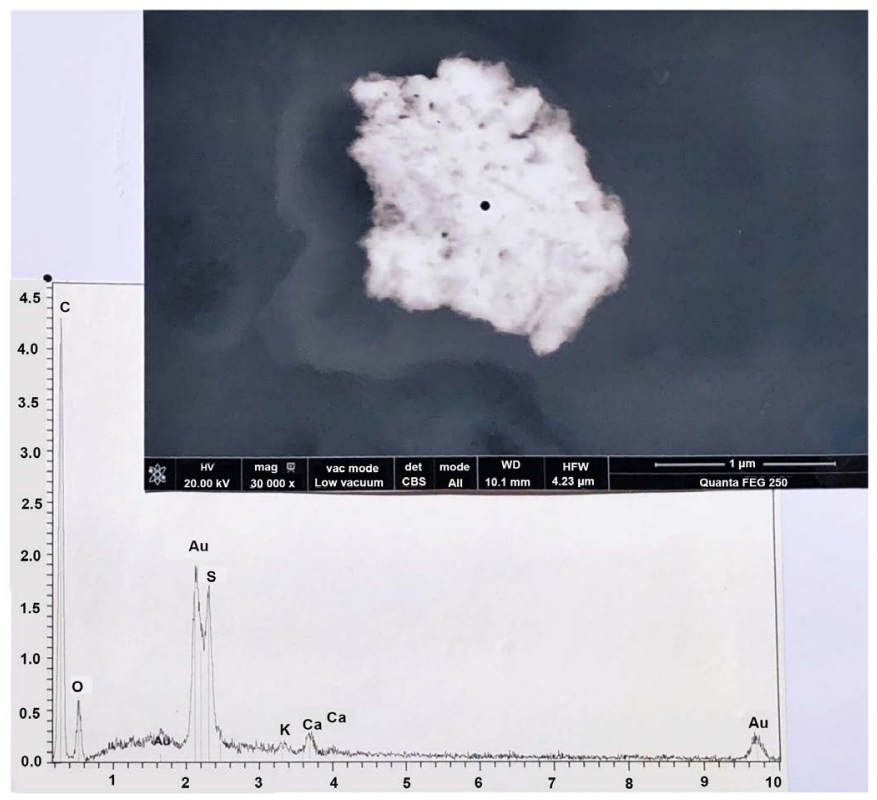

Figure 16. A scale of pure gold, located on hair number 9. Above: SEM photograph (in CBS, 30000x) of the scale. Below: spectrum at the black point. C: carbon; O: oxygen; $\mathrm{Au}$ (two peaks): gold; S: sulphur; K: potassium; Ca (two peaks): calcium. 
particles are present in number on hairs numbers 1, 2 and 6. Supplementary Figure 6 shows a white-to-electrons particle, located on the hair number 6 border near a transversal alteration of that hair. It is complex in form, compounded of little spherical (showing that it corresponds to some material in fusion) sub-particles. Elemental analysis establishes that it is mainly of pure iron. Such spherical sub-particles, isolated or lumped together, were found on the surfaces of hairs numbers 1, 2 and 3. There are also numerous little particles (of pure or of oxided iron), of various forms, on all hair surfaces; they correspond to common industrial modern pollutants. Supplementary Figure 7 shows a very little (of about $1 \mu \mathrm{m}$ ) particle, located on hair number 1. It is compounded of iron sulphate, a third common phytosanitary product. Such particles, in isolated form or in groups, are found on hair number 2, 3, 5, 9 and 10.

\subsubsection{Titanium}

Supplementary Figure 8 shows a rod of titanium, located on some part of hair number 3. It is compounded of titanium dioxide $\left(\mathrm{TiO}_{2}\right)$, the most common metallic pollutant after iron. Two other samples of such a rod are found on other parts of hair number 3. Supplementary Figure 9 shows a micro-ball of titanium, located on hair number 10 (elemental analysis establishes that titanium is the metallic component of this micro-ball). This unique observation corresponds probably to a droplet of modern white colorant (of titanium), loaded on a bed of calcium carbonate.

\subsubsection{Aluminium}

Supplementary Figure 10 shows three micro-fragments of aluminium, located at the border of hair number 1; they caused here a local alteration of the hair surface. Elemental analysis establishes that the aluminium is of the oxided form (it corresponds so to a modern aluminium scrop).

\subsubsection{Mercury}

Supplementary Figure 11 and Supplementary Figure 12 show two micro-drops of mercury, located on hair number 1. Elemental analysis of these micro-drops shows that they are compounded of cinnabar ( $\mathrm{HgS})$, a red colorant used since the Middle Age to imitate blood spots (Lucotte et al., 2016). A third micro-drop of cinnabar, located on hair number 3, is shown on Supplementary Figure 13.

\subsection{Calcium Phosphate Particles}

All of the ten hairs studied have deposits of calcium phosphate on their surfaces. That is important to consider, because hydroxyapatite remains the mineral component found in ancient bones (Lucotte \& Thomasset, 2017c).

In some cases the calcium phosphate deposit is very thin (Figure 17); but often this thin deposit is arranged in longitudinal line running along the hair surface (Figure 18). Locally the calcium phosphate deposit can also be thick (with more mineral matter contained in its), constituting a bone scale with acute borders (Figure 19). 


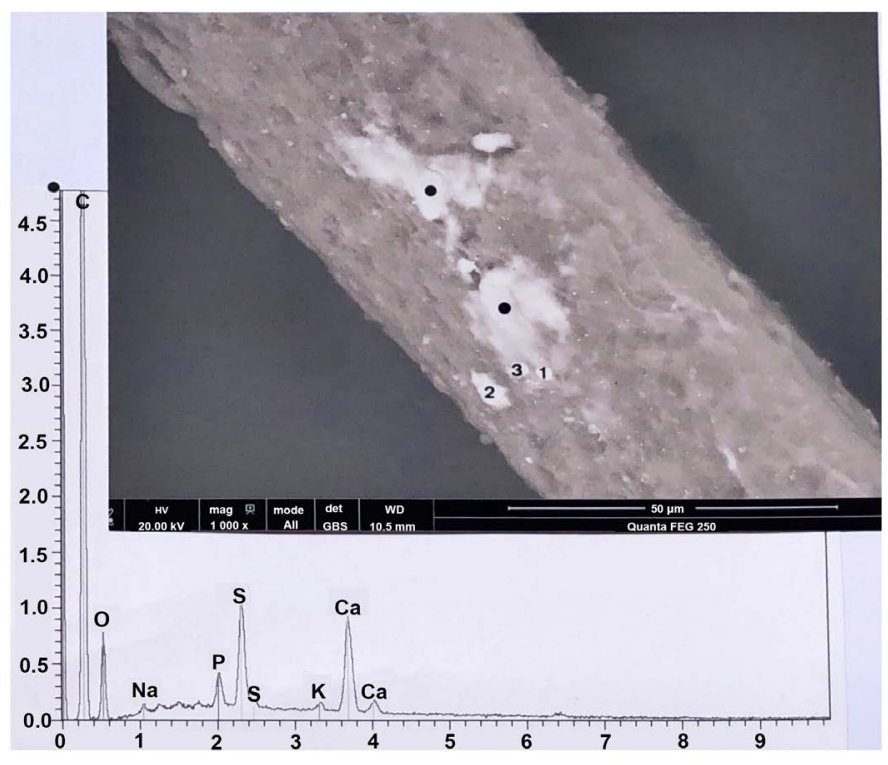

Figure 17. An example of a thin deposit of calcium phosphate, located in some part of hair number 3. Above: SEM photograph (in CBS, $1000 \times)$ of the deposit (1-3: calcite particles). Below: spectrum at the black points. C: carbon; O: oxygen; Na: sodium; P: phosphorous; $\mathrm{S}$ (two peaks): sulphur; K: potassium; $\mathrm{Ca}$ (two peaks): calcium.

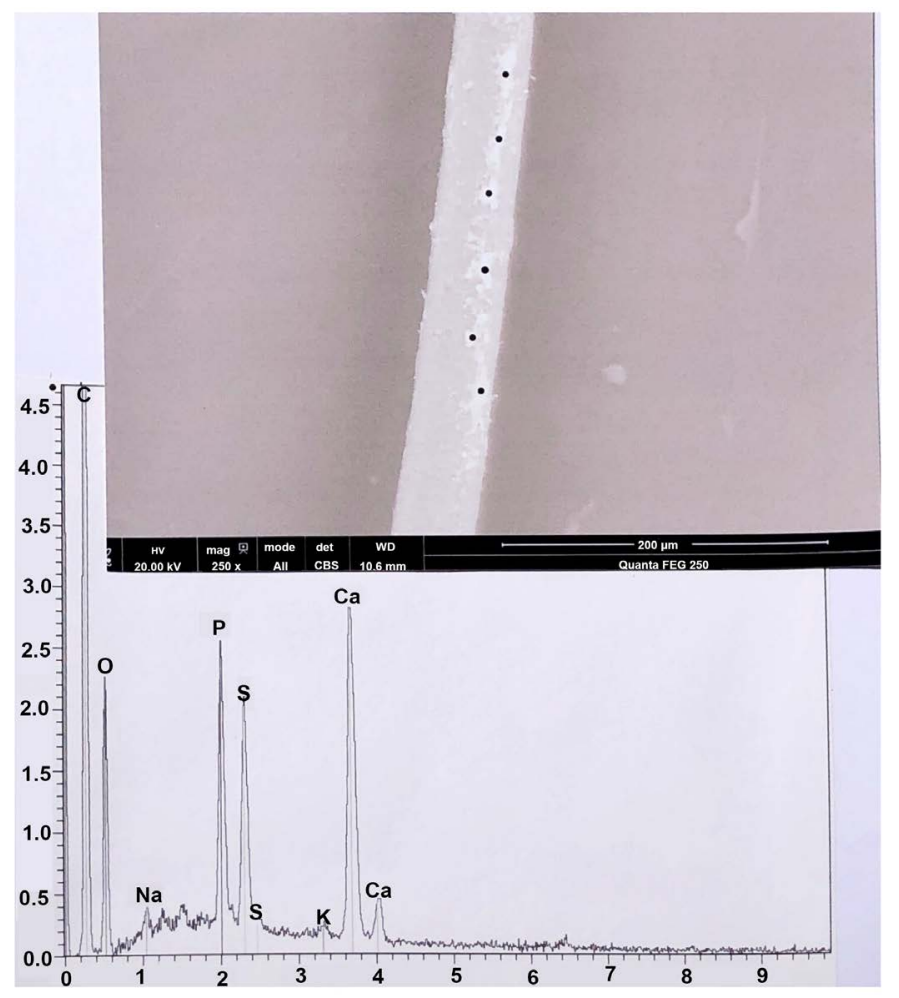

Figure 18. Longitudinal line of six calcium phosphate deposits in another part of hair 3. Above: SEM photograph (in CBS, 250x) of the line. Below: spectrum at the black points. C: carbon; O: oxygen; Na: sodium; P: phosphorous; S (two peaks): sulphur; K: potassium; $\mathrm{Ca}$ (two peaks): calcium. 




Figure 19. Example of a bone scale (in another part of hair 3). Above: SEM photograph (in CBS, $2400 \times$ ) of the bone scale. Below: spectrum at the black point. C: carbon; O: oxygen; Na: sodium; Mg: magnesium; Al: aluminium; Si: silicium; P: phosphorous; S (two peaks): sulphur; K: potassium; Ca (two peaks): calcium.

In other cases the bone scales appear clearly as loaded on the hair surface (Figure 20). The most extreme situation of osseous scale loading is represented on Figure 21: a voluminous (of more than $50 \mu \mathrm{m}$ of maximal length) scale of calcium phosphate, very thick and longitudinally fragmented.

In summary, I found on the hairs numerous particles of silver and gold, but also some metallic particles of copper, lead, iron, titanium, aluminium and mercury. All the hairs have deposits of calcium phosphate on their surfaces.

Table 1 summarizes all the observations on calcium phosphate deposits on each hair studied. That suggests a previous close and prolonged contact between these hairs and some bone. We have a representation (Figure 22) of the ancient (since 1283 to 1793) bust-reliquary of Maria-Magdalena: that is a bust of gold, where her cranium was loaded; the cranium, with adhering hairs, was surmounted by a crown of gold (that of Charles $1^{\text {er }}$ d'Anjou). In this 1283 reliquary, hairs framed the cranium. It is probable that calcium phosphate deposits observed result from narrow contact (during about fifty centuries) of hairs adhering to the cranium. 


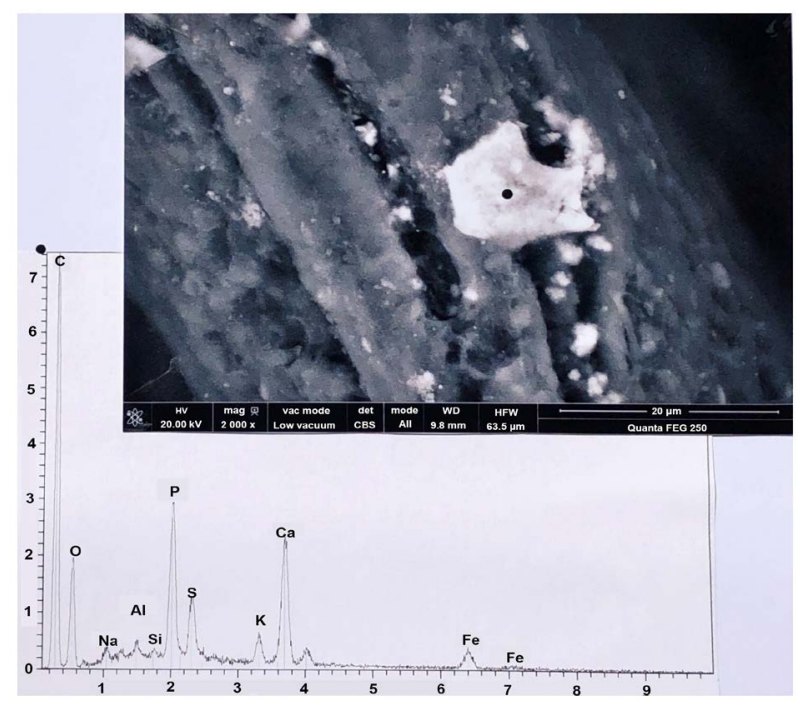

Figure 20. A bone scale, located on hair number 6. Above: SEM photograph (in CBS, 2000×) of the scale. Below. spectrum at the black point. C: carbon; O: oxygen; Na: sodium; Al: aluminium; Si: silicium; P: phosphorous; S: sulphur; K: potassium; $\mathrm{Ca}$ (two peaks): calcium; Fe (two peaks): iron.

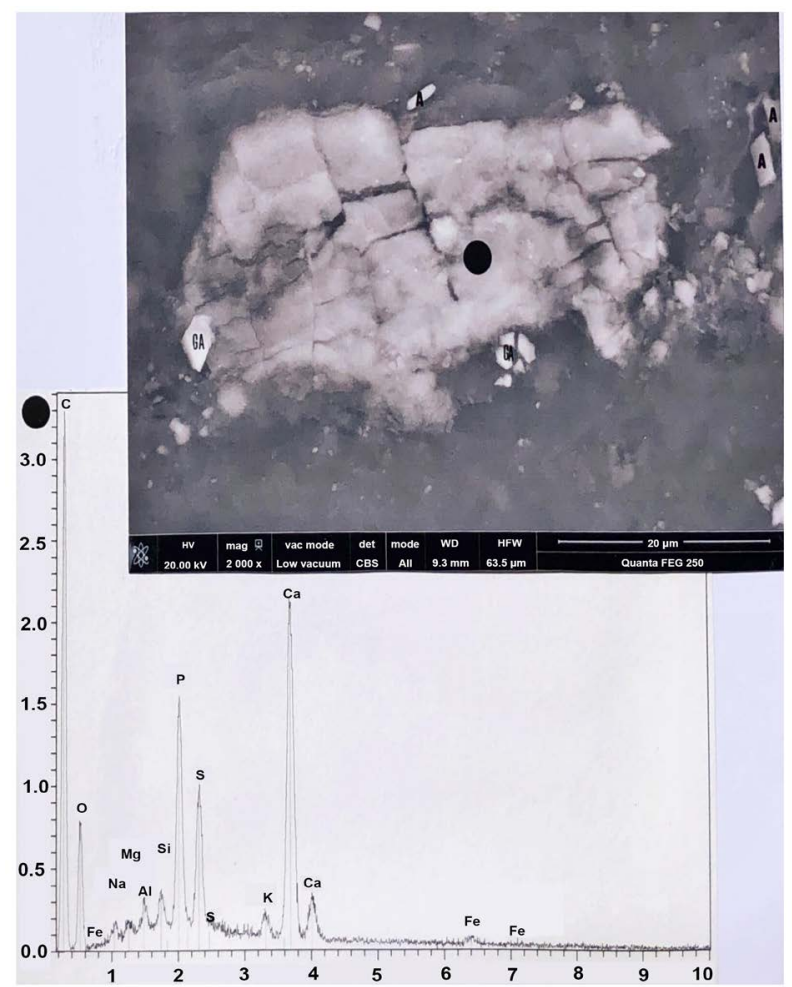

Figure 21. A thick plaque of bone, located on hair number 9. Above: SEM photograph (in CBS, 2000x) of the plaque. A: aragonite particles; CA: calcite particles. Below. spectrum at the black point. C: carbon; O: oxygen; Fe (three littles peaks): iron; Na: sodium; Mg: magnesium; Al: aluminium; Si: silicium; P: phosphorous; S (two peaks): sulphur; K: potassium; Ca (two peaks): calcium. 




Figure 22. The ancient (since 1283) bust-reliquary of Maria-Magdalena. $\mathrm{N}$ : golden mask; L: crown of gold; R: bust-reliquary of gold (source: collection Lallemant de Betz; Bibliothèque Nationale de France, Paris).

Table 1. Calcium phosphate deposits found on hairs.

\begin{tabular}{|c|c|c|}
\hline Hair number & Different sorts & Corresponding figures \\
\hline 1 & $\begin{array}{ll}\cdot & \text { a thin deposit } \\
\cdot & \text { a thick deposit }\end{array}$ & \\
\hline 2 & - a thick deposit & \\
\hline & $\begin{array}{l}\text { a thin deposit } \\
\text { - four thin deposits arranged } \\
\text { longitudinally } \\
\text {. a thin deposit } \\
\text {. four thick deposits arranged } \\
\text { longitudinally }\end{array}$ & Figure 17 \\
\hline 3 & two thin deposits & Figure 18 \\
\hline & $\begin{array}{ll}\text { - } & \text { Four thin deposits } \\
\text { - } & \text { six thin deposits arranged } \\
\text { longitudinally } \\
\text {. } \\
\text { a trail of thin deposits } \\
\text {. } & \text { a thin deposit } \\
\text { a bone scale }\end{array}$ & Figure 19 \\
\hline 6 & $\begin{array}{l}\text { a thin bone scale } \\
\text {. a thick bone scale }\end{array}$ & Figure 20 \\
\hline 7 & $\begin{array}{l}\text { three thick deposits arranged } \\
\text { longitudinally }\end{array}$ & \\
\hline 9 & $\begin{array}{l}\text {. } \text { two thin deposits } \\
\text {. }\end{array}$ & Figure 21 \\
\hline
\end{tabular}

Table 2 summarizes all the observations of gold particles on hairs. Probably most of them (particularly those that are of pure gold) are due to close contact between hairs and the gold of the bust-reliquary and that of the crown.

Silver particles (Table 3) are more difficult to explain. But we know (Franzoni, 2016) that Maria-Magdalena's remains were initially (since 1281) kept in a 
Table 2. Gold deposits found on hairs.

\begin{tabular}{|c|c|c|}
\hline Hair number & Different sorts & Corresponding figures \\
\hline 1 & $\begin{array}{ll}\cdot & \text { a plaque of gold alloy }(\mathrm{Au} / \mathrm{Ag}) \\
\cdot & \text { Four little particles of a gold powder } \\
\text {. } & \text { two little particles of a gold powder } \\
\cdot & \text { a second plaque of gold alloy }(\mathrm{Au} / \mathrm{Ag} / \mathrm{Cu})\end{array}$ & $\begin{array}{l}\text { Figure } 12 \\
\text { Figure } 13\end{array}$ \\
\hline 2 & $\begin{array}{l}\text { three little particles of a gold alloy }(\mathrm{Au} / \mathrm{Ag} / \mathrm{Cu}) \text { powder } \\
\text {. } \\
\text { a little poly-lobed particle of a gold alloy }(\mathrm{Au} / \mathrm{Ag} / \mathrm{Cu}) \\
\text { sixtle particles of a gold powder }\end{array}$ & Figure 9 \\
\hline 3 & $\begin{array}{ll}\cdot & \text { a particle of gold alloy }(\mathrm{Au} / \mathrm{Ag} / \mathrm{Cu}) \\
\cdot & \text { a plaque of gold alloy }(\mathrm{Au} / \mathrm{Cu}) \\
\cdot & \text { two particles of gold alloy }(\mathrm{Au} / \mathrm{Ag} / \mathrm{Cu}) \\
& \text { three particles of a gold alloy }(\mathrm{Au} / \mathrm{Ag} / \mathrm{Cu}) \text { of a powder }\end{array}$ & $\begin{array}{l}\text { Figure } 10 \\
\text { Figure } 11 \\
\text { Figure } 15\end{array}$ \\
\hline 9 & $\begin{array}{l}\text { a little plaque of pure gold } \\
\text {. } \\
\text { grains of pure gold dust } \\
\text { a particle of pure gold }\end{array}$ & $\begin{array}{l}\text { Figure } 14 \\
\text { Figure } 16\end{array}$ \\
\hline
\end{tabular}

Table 3. Silver deposits found on hairs.

\begin{tabular}{|c|c|c|}
\hline Hair number & Different sorts & $\begin{array}{l}\text { Corresponding } \\
\text { figures }\end{array}$ \\
\hline 1 & $\begin{array}{l}\text { a particle that is a mixture of silver sulphide and chloride } \\
\text { - a particle of silver sulphide and gold } \\
\text { a plaque of silver with copper } \\
\text { a granulous particle of silver sulphide } \\
\text { a little particle of silver sulphide }\end{array}$ & $\begin{array}{l}\text { Figure } 5 \\
\text { Figure } 6 \\
\text { Figure } 7\end{array}$ \\
\hline 2 & $\begin{array}{l}\text { a little particle of silver sulphide } \\
\text { about fifteen particles of silver sulphide arranged among the } \\
\text { longitudinal axis of the hair } \\
\text { one plaque of silver chloride on the border of the hair } \\
\text { two plaques of silver chloride on the border of the hair } \\
\text { one plaque of silver chloride on the border of the hair }\end{array}$ & $\begin{array}{l}\text { Figure } 2 \\
\text { Figure } 3 \\
\text { Figure } 4\end{array}$ \\
\hline 3 & $\begin{array}{l}\text { a little plaque of silver sulphide } \\
\text { a particle of silver sulphide/chloride } \\
\text { many little plaques of silver sulphide (with copper traces), } \\
\text { arranged longitudinally } \\
\text { two little plaques of silver sulphide } \\
\text { - eight little plaques of silver sulphide arranged longitudinally } \\
\text { a turmoiled little particle of silver sulphide }\end{array}$ & \\
\hline 4 & - a large plaque of pure silver & Figure 8 \\
\hline 9 & $\begin{array}{l}\text { two little plaques of silver sulphide } \\
\text { - one little pile of particles of silver sulphide, with copper }\end{array}$ & \\
\hline
\end{tabular}

silver reliquary; possibly some of the silver particles observed on hairs were due to initial contact with the inner side of the reliquary.

\section{Conclusion}

We observed on all hairs studied many deposits of calcium phosphate. Their 
forms differ: sometimes it is a very thin layer of calcium phosphate loaded on the surface of the hairs; but it can be a thicker deposit, with visible borders. Sometimes they consist of plaques of calcium phosphate that mimic a true osseous structure. The trails of calcium observed are often arranged in longitudinal lines along the hair corpus.

Such observations indicate a previous close contact between hairs and some bone. We know that hairs covered cranium in the historical (between 1283 and 1793) bust-reliquary (see Figure 22) where Maria-Magdalena remains were kept. It is during this long time period that the hydroxyapatite of the cranium loaded on hairs.

Because the bust-reliquary was of gold (and also the crown that covered hairs), some of the gold plaques observed on some hairs (particularly those that are of pure gold, like that of Figure 16) can be detached among time from the gold of the bust-reliquary to the hair surface. Generally, gold particles deposited on hairs are made of an alloy of gold with little amounts of silver and copper.

The numerous plaques or silver sulphide (or/and chloride) observed at the surface of some hairs are more difficult to explain; often these plaques are also orientated in longitudinal lines along the hair surface. Because we know that the initial (since 1281) reliquary where the Maria-Magdalena remains were kept was of silver, we suppose that some of the silver plaques observed (particularly those that are of pure silver, like that of Figure 8) were also detached among time from the silver of the inner side of this reliquary.

Other metallic particles observed at the hair surfaces are in fact explained as residues of deposits from the current reliquary, or as traces of phytosanitary products or colorants, or as modern industrial metallic pollutants.

\section{Acknowledgements}

We thank F. Racine, the priest of Saint-Maximin-la-Sainte-Baume, who furnished Maria-Magdanena's hairs. Thank you also to T. Thomasset (UTC of Compiègne) for his assistance on the SEM. The present article is a development of some part of the conference I have pronounced at the Saint-Maximin-basilica on the $23^{\text {rd }}$ of July 2016.

\section{Conflicts of Interest}

The author declares no conflicts of interest regarding the publication of this paper.

\section{References}

Franzoni, A. (2016). Sainte Marie-Madeleine et les Saints de Provence dans la Tradition Provençale (Vol. 3). Sainte-Baume: Editions ASTSP.

Lucotte, G. (2016). The Mitochondrial DNA Mitotype of Sainte Marie-Madeleine. International Journal of Sciences, 5, 10-19. https://doi.org/10.18483/ijSci.1167

Lucotte, G., \& Thomasset, T. (2017a). Study of the Red Colour of Ste Marie-Madeleine $(\approx 3-63)$ Hair by Scanning Electron Microscopic Characterization of Its Melanosomes. 
Journal of Dermatology and Pigmentation Research, 1, 108-116.

Lucotte, G., \& Thomasset, T. (2017b). Scanning Electron Microscopy Characterization and Elemental Analysis of One Hair Located on the Face of the Turin Shroud. Archaeological Discovery, 5, 1-21. https://doi.org/10.4236/ad.2017.51001

Lucotte, G., \& Thomasset, T. (2017c). An Osseous Remain on the Face of the Turin Shroud. Journal of Anthropology and Archaeology, 5, 20-38. https://doi.org/10.15640/jaa.v5n1a3

Lucotte, G., D’Hérissart, E., \& Thomasset, T. (2019). Marine Micro-Remains on Holy Maria-Magdalena's Hair, Studied by Scanning Electron Microscopy and Elemental Analysis. Archaeological Discovery, 7, 155-191. https://doi.org/10.4236/ad.2019.73009

Lucotte, G., Derouin, T., \& Thomasset, T. (2016). Hematite, Biotite and Cinnabar on the Face of the Turin Shroud: Microscopy and SEM-EDX Analysis. Open Journal of Applied Sciences, 6, 601-625. https://doi.org/10.4236/ojapps.2016.69059

Lucotte, G., Thomasset, T., \& Salmon, A. (2018). Fennel (Foeniculum vulgare) Rests on the Holy Maria-Magdalena's Hairs, Studied by Scanning Microscopy and Elemental Analysis. Archaeological Discovery, 6, 216-270. https://doi.org/10.4236/ad.2018.63012

Trouillet, M. C. (2016). Les Reliques de Ste Marie-Madeleine. Petrus: Aix-en-Provence. 


\section{Supplementary Figures}

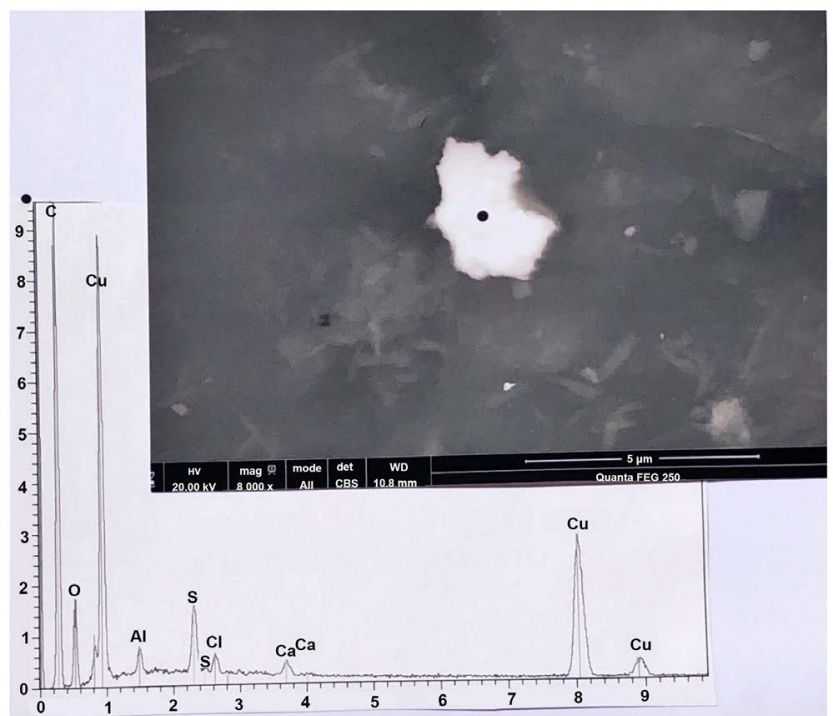

Figure S1. A plaque of copper, located on hair number 3. Above. SEM photograph (in CBS, $8000 \times$ ) of the plaque. Below. spectrum at the black point. $\mathrm{C}$ : carbon, $\mathrm{O}$ : oxygen; $\mathrm{Cu}$ (three peaks): copper; Al: aluminium; $\mathrm{S}$ (two peaks): sulphur; $\mathrm{Cl}$ : chlorine; $\mathrm{Ca}$ (two peaks): calcium.

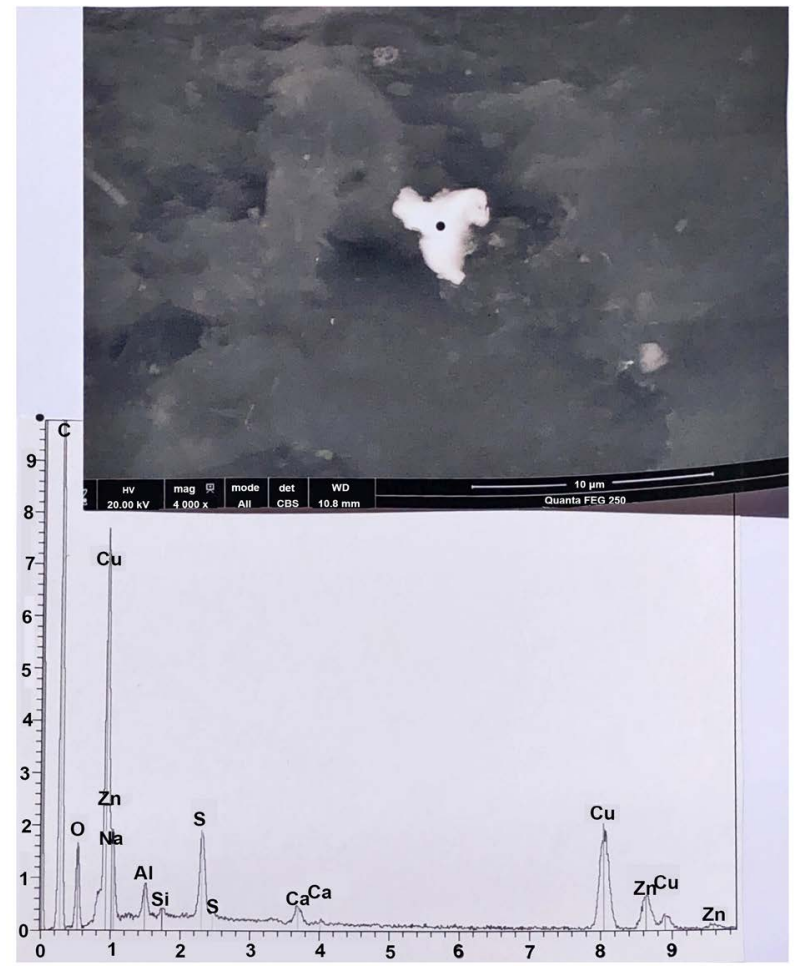

Figure S2. A plaque of brass, located on hair number 3. Above: SEM photograph (in CBS, $4000 \times$ ) of the plaque. Below. spectrum at the black point. C: carbon; O: oxygen; $\mathrm{Cu}$ (three peaks): copper; Zn (three peaks): zinc; Na: sodium; Al: aluminium; Si: silicium; S (two peaks): sulphur; Ca (two peaks): calcium. 




Figure S3. Particles of copper sulphate, located in one part of hair number 6. Above: SEM photograph (in CBS, 2000×) of the group of particles (m: mycelium; s: spores). Below: spectrum at the black points. C: carbon; O: oxygen; $\mathrm{Cu}$ (three peaks): copper; $\mathrm{Al}$ : aluminium; S: sulphur; K: potassium; Ca (two peaks): calcium.

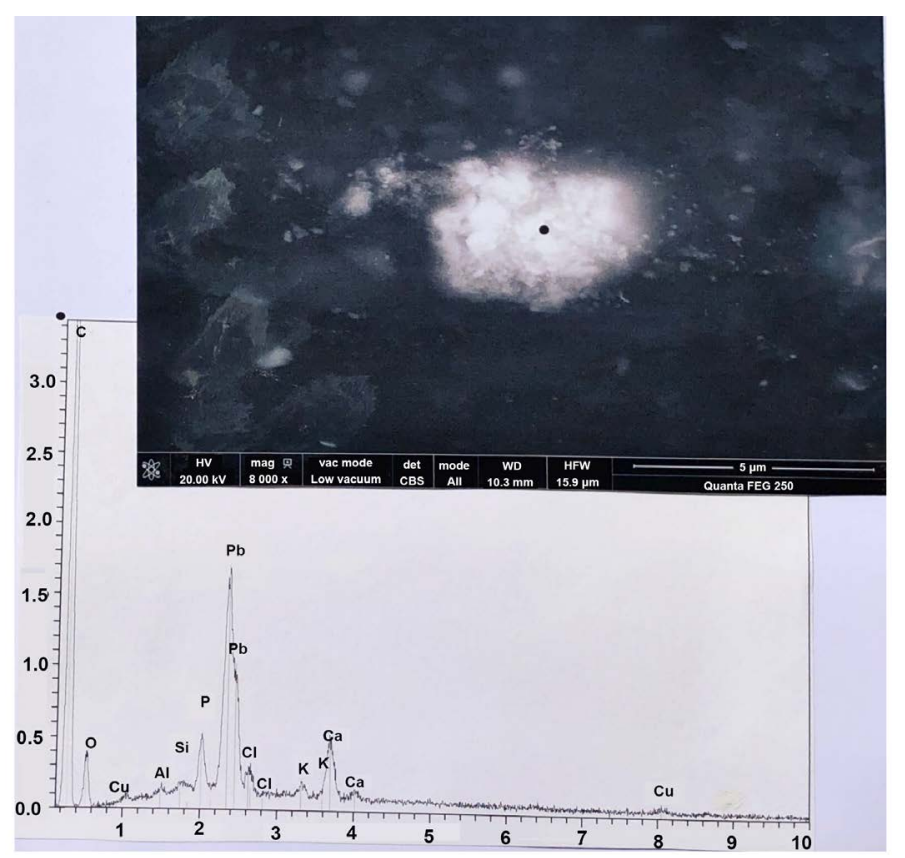

Figure S4. A particle of lead phosphate, located on hair number 9. Above: SEM photograph (in CBS, $8000 \times$ of the particle). Below: spectrum at the black point. C: carbon; O: oxygen; $\mathrm{Cu}$ (two peaks): copper; Al: aluminium; Si: silicium; $\mathrm{P}$ : phosphorous; $\mathrm{Pb}$ (two peaks): lead; $\mathrm{Cl}$ (two peaks): chlorine; $\mathrm{K}$ (two peaks): potassium; $\mathrm{Ca}$ (two peaks): calcium. 


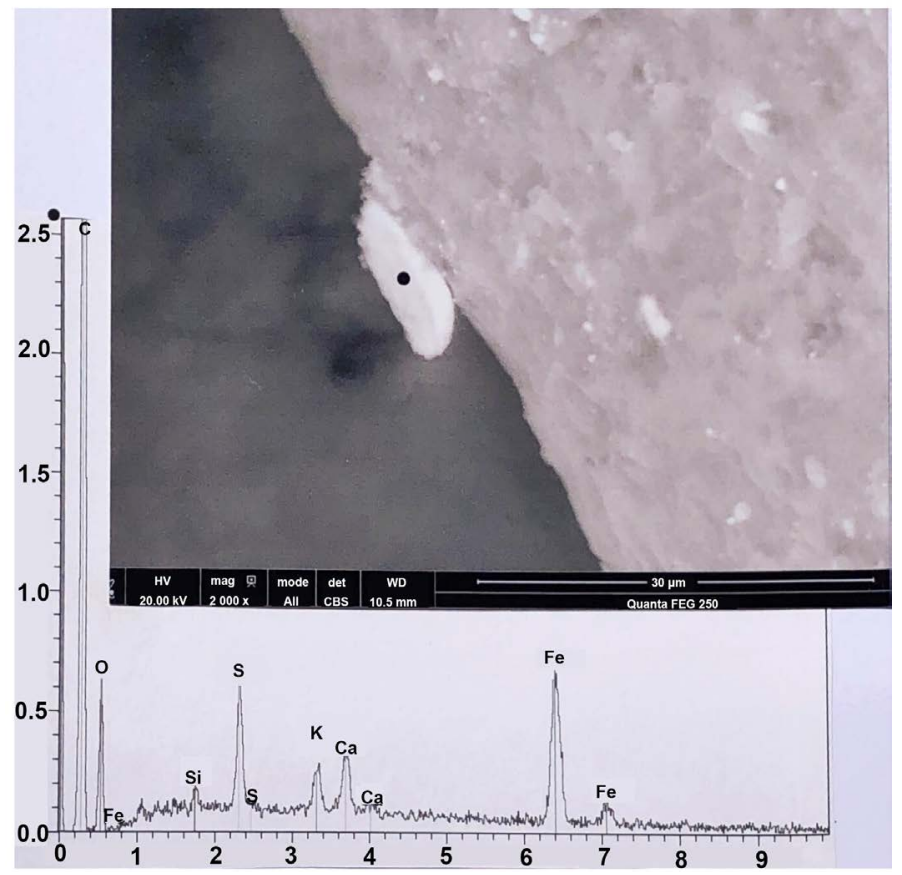

Figure S5. A particle of iron oxide, located on the border of hair number 3. Above: SEM photograph (in CBS, 2000×) of the particle. Below. spectrum at the black point. C: carbon; O: oxygen; $\mathrm{Fe}$ (three peaks): iron; Si: silicium; $S$ (two peaks): sulphur; K: potassium; $\mathrm{Ca}$ (two peaks): calcium.

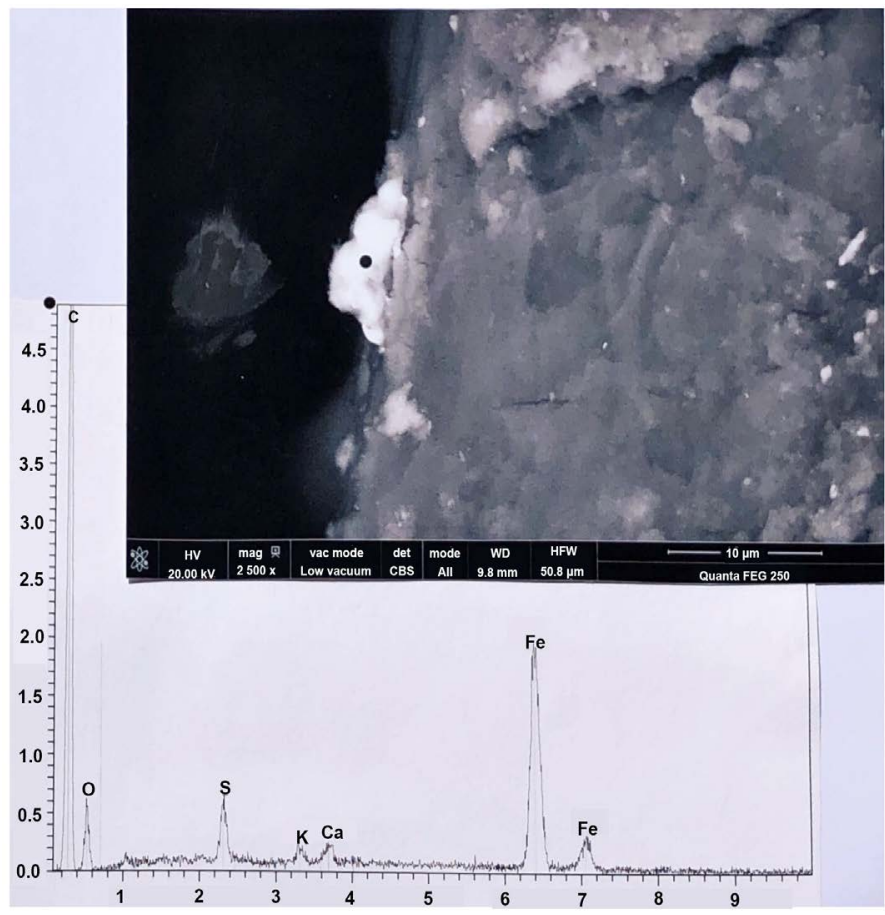

Figure S6. Particles of iron, located at the border of hair number 6 . Above: SEM photograph (in CBS, 2500x) of the group of particles. Below: spectrum at the black point. C: carbon; O: oxygen; S: sulphur; $\mathrm{K}$ : potassium; Ca: calcium; Fe (two peaks): iron. 


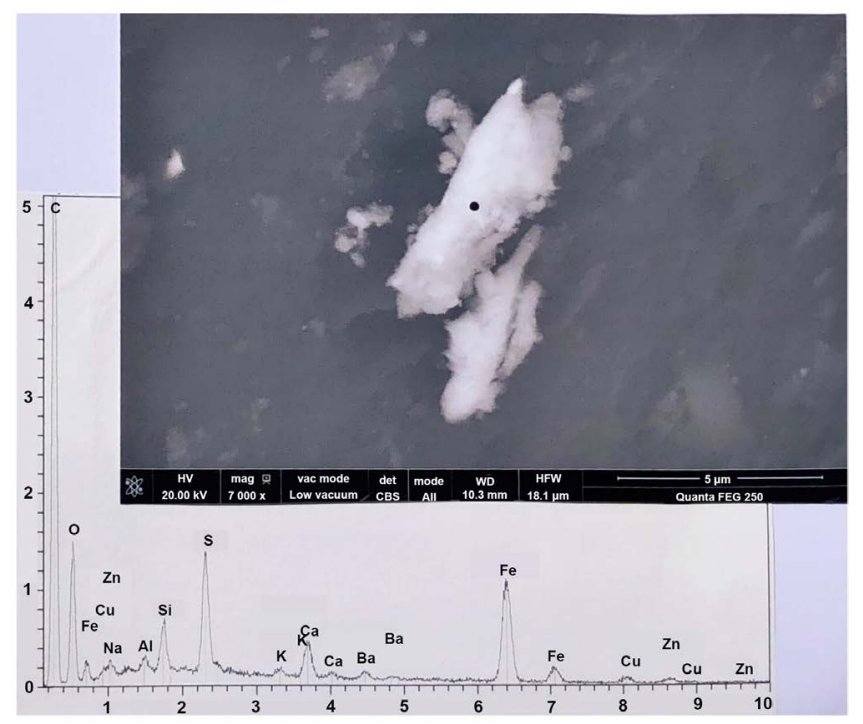

Figure S7. A particle of iron sulphate, located on hair number 1 . Above: SEM photograph (in CBS, 5000x) of the particles (4: particle of iron sulphate; 3: particle of copper sulphate; 5: two particles of calcite). Upper spectrum (that of particle 4). C: carbon; O: oxygen; Fe (three peaks): iron; Na: sodium; Mg: magnesium; Al: aluminium; Si: silicium; S (two peaks): sulphur; K: potassium; Ca (two peaks): calcium. Lower spectrum (that of particle 3).C: carbon; O: oxygen; $\mathrm{Cu}$ (three peaks): copper; $\mathrm{Na}$ : sodium; Mg: magnesium; Al: aluminium; S (two peaks): sulphur; K: potassium; Ca (two peaks): calcium; that spectrum corresponds to a particle of copper sulphate.



Figure S8. A rod of titanium, located on hair number 3. Above: SEM photograph (in CBS, 16000×) of the rod. Below: spectrum at the black point. C: carbon; O: oxygen; Na: sodium; Al: aluminium; Si: silicium; S (two peaks): sulphur; K: potassium; Ca (two peaks): calcium; Ti (two peaks): Titanium. 


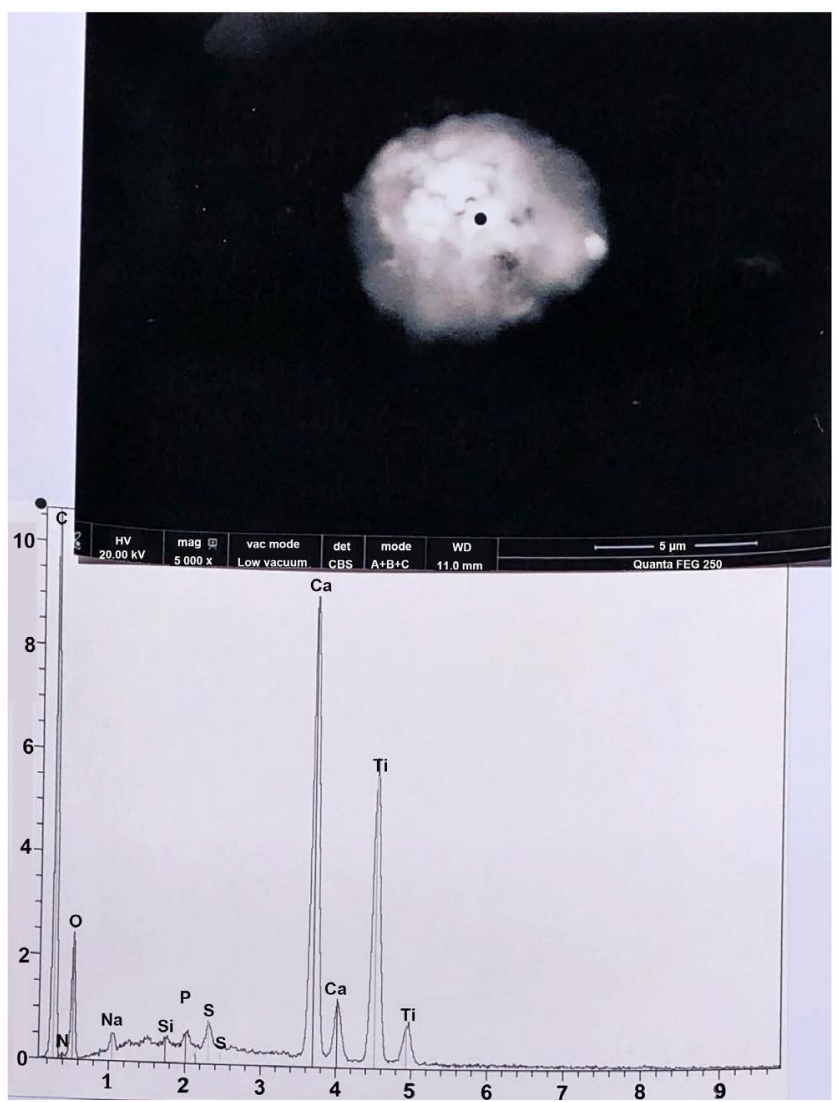

Figure S9. A micro-ball of titanium, located on hair number 10. Above: SEM photograph (in CBS, 5000x) of the micro-ball. Below: spectrum at the black point. C: carbon; N: nitrogen; O: oxygen; Na: sodium; Si: silicium; P: phosphorous; S (two peaks): sulphur; $\mathrm{Ca}$ (two peaks): calcium; Ti (two peaks): titanium.

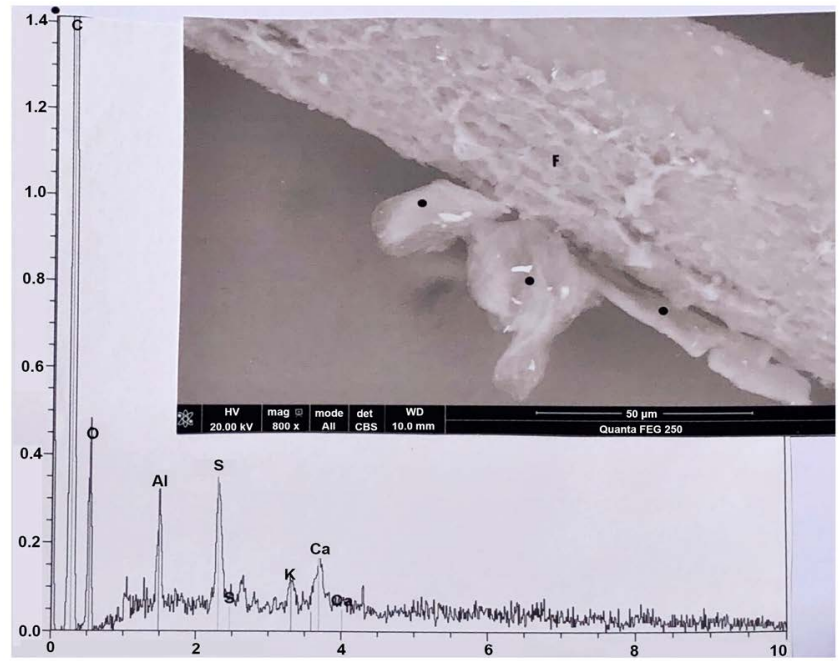

Figure S10. Micro-fragments of aluminium, located at the border of hair number 1. Above: SEM photograph (in CBS, 800x) of the three micro-fragments (F: weaked zone of the hair). Below: spectrum of the micro-fragments. C: carbon; O: oxygen; Al: aluminium; S (two peaks): sulphur; K: potassium; Ca (two peaks): calcium. 


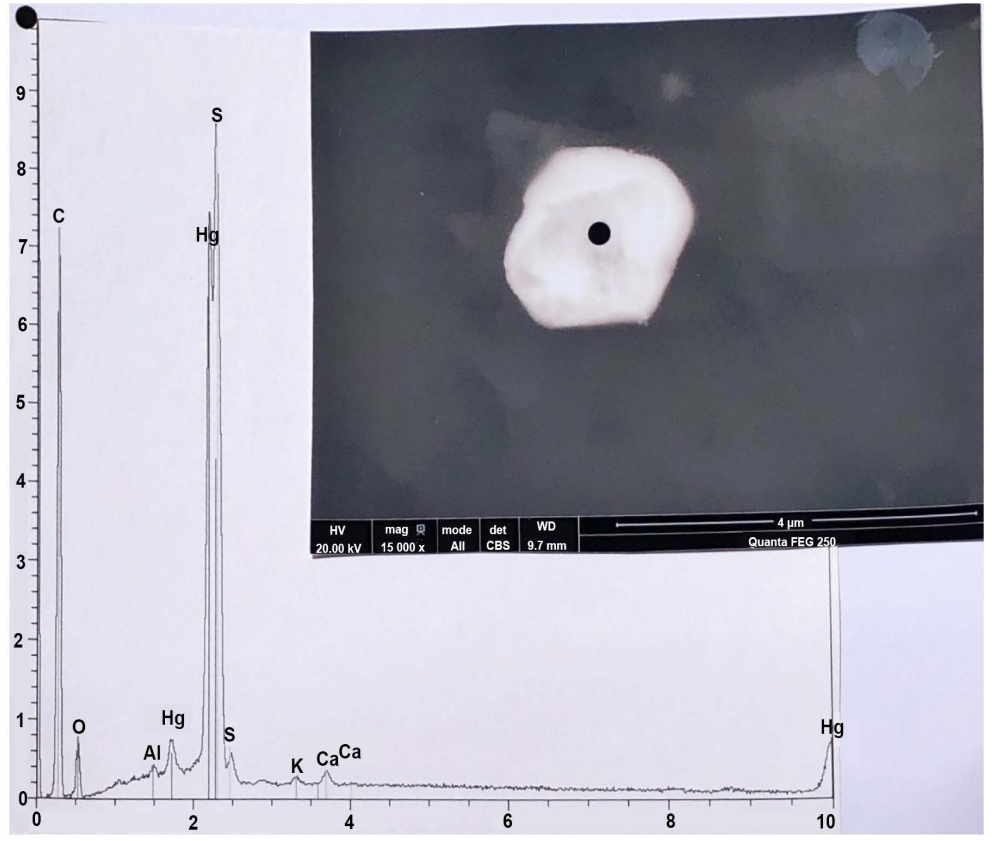

Figure S11. A first micro-drop of mercury, located on hair number 1 . Above: SEM photograph (in CBS, 15000×) of the micro-drop. Below. spectrum at the black point. C: carbon; O: oxygen; $\mathrm{Al}$ : aluminium; $\mathrm{Hg}$ (three peaks): mercury; S (two peaks): sulphur; K: potassium; Ca (two peaks): calcium.

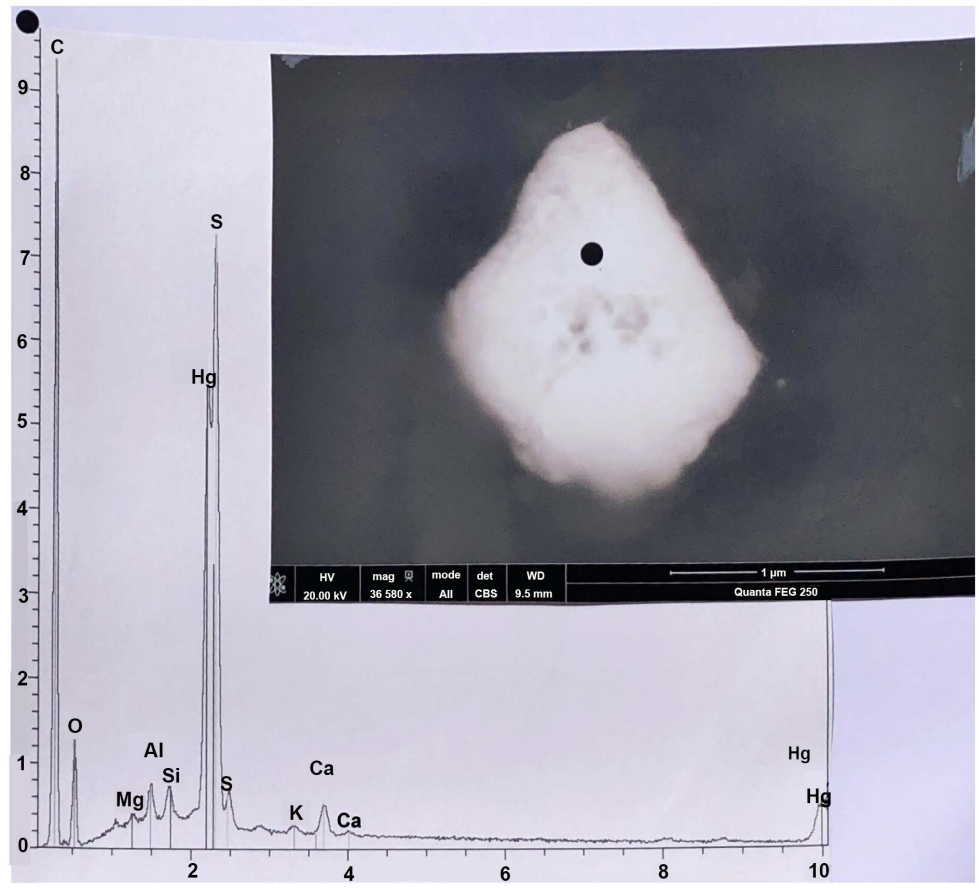

Figure S12. A second micro-drop of mercury, located on hair number 1 . Above: SEM photograph (in CBS, 36580×) of the microdrop. Below. spectrum at the black point. C: carbon; O: oxygen; $\mathrm{Mg}$ : magnesium; $\mathrm{Al}$ : aluminium; Si: silicium; Hg (two peaks): mercury; S (two peaks): sulphur; K: potassium; Ca (two peaks): calcium. 


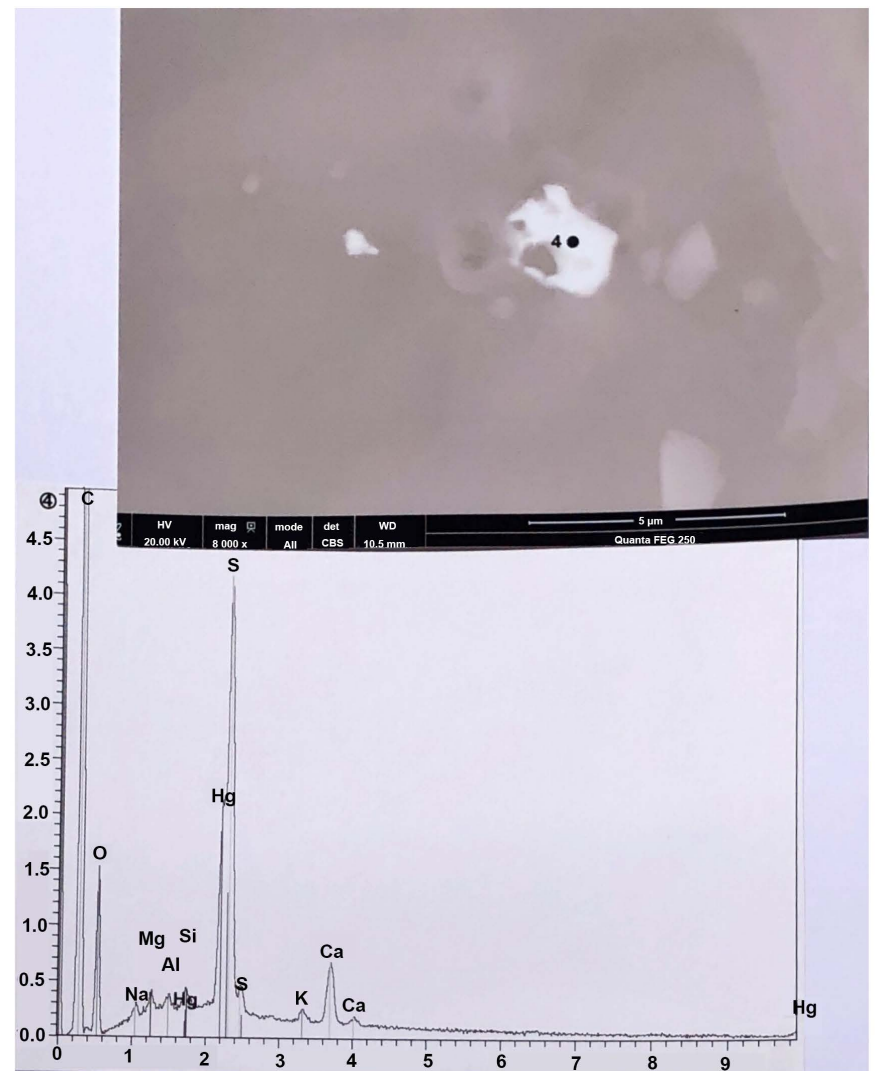

Figure S13. A third micro-drop of mercury, located on hair number 3. Above: SEM photograph (in CBS, $8000 \times$ ) of the micro-drop (4: the micro-drop). Below: spectrum of 4. C: carbon; O: oxygen; Na: sodium; $\mathrm{Mg}$ : magnesium; Al: aluminium; $\mathrm{Hg}$ (three peaks): mercury; Si: silicium; S (two peaks): sulphur; K: potassium; Ca (two peaks): calcium. 